\title{
Age, growth and reproductive biology of diamond-shaped squid Thysanoteuthis rhombus (Oegopsida: Thysanoteuthidae)*
}

\author{
Chingiz M. Nigmatullin ${ }^{1}$, Alexander I. Arkhipkin ${ }^{1, *}$, Rushan M. Sabirov ${ }^{2}$ \\ 'Atlantic Research Institute of Marine Fisheries and Oceanography (AtlantNIRO), 5 Dmitry Donskoy St., \\ Kaliningrad 236000, Russia \\ ${ }^{2}$ Kazan State University, 18 Lenin St., Kazan 420008, Russia
}

\begin{abstract}
Age and growth of the large oceanic squid Thysanoteuthis rhombus were estimated by statolith increment analysis of 72 specimens [mantle length (ML) ranging from 25 to $805 \mathrm{~mm}$ ) and reproductive biology was studied on 162 T. rhombus (ML 150 to $850 \mathrm{~mm}$ ) captured in the eastern tropical Atlantic and southwestern Pacific between 1976 and 1990. The maximum ages found in our samples were observed in a mature female of $750 \mathrm{~mm} \mathrm{ML}(305 \mathrm{~d})$ and in a mature male of $770 \mathrm{~mm} \mathrm{ML}$ (309 d). The life span of $T$. rhombus was estimated to be about 1 yr; males and females matured at age 6 to 8 mo. T. rhombus is one of the fastest-growing squids: by age $300 \mathrm{~d}$, they reached 750 to $800 \mathrm{~mm}$ $\mathrm{ML}$ and 17 to $17.5 \mathrm{~kg}$ body weight (BW). The increase in both ML and BW during ontogenesis was best fitted by a logistic growth curve. T rhombus has high potential fecundity (up to 4.8 million oocytes), but a rather small maximum volume of oviducts (up to 140000 eggs) and egg masses (35000 to 75000 eggs). It is suggested that $T$ rhombus is an intermittent spawner with multiple filling and evacuation of oviducts. The main function of the (for squid) unusual behaviour of $T$ rhombus, i.e. living in pairs consisting of a male and female, is reproduction and is optimal given the low density of $T$ rhombus populations and low active movement of squids
\end{abstract}

KEY WORDS: Statolith · Growth - Reproduction - Thysanoteuthis rhombus S Squid

\section{INTRODUCTION}

The diamond-shaped squid Thysanoteuthis rhombus Troschel, 1857 is the only species of the family Thysanoteuthidae. This squid is a non-abundant epipelagic inhabitant of warm tropical and partially subtropical waters (water temperature $>20$ or $21^{\circ} \mathrm{C}$, usually 23 to $26^{\circ} \mathrm{C}$ ) of the World Ocean and the Mediterranean. The squid penetrates into the upper latitudes of subtropical and temperate waters (the Japan Sea, waters of South Africa and America) with warm currents (the Tsushima, Kuroshio, Agulhas and Brazil Currents, and the Gulf

\footnotetext{
- To the memory of the kind and marvellous smile of Prof. Gilbert L. Voss - a great man, scientist and teacher

- Addressee for correspondence

E-mail: root@atlant.koenig.su
}

Stream) (Arkhipkin et al. 1983, Roper et al. 1984, Nesis 1985). Nazumi (1975) observed that a sudden drop of temperature below 14 to $15^{\circ} \mathrm{C}$ in the depth range 0 to $100 \mathrm{~m}$ caused a decrease in activity and even death of squids in the Japan Sea. Because of this, T. rhombus were sometimes found dying in nearshore waters or stranded ashore at the outer edges of the species range (Pfeffer 1912, Barnard 1947, Bruggen 1962, Nishimura 1966, Morales 1981, Roeleveld \& Pheiffer 1987). These strange-looking, large animals [max. mantle length (ML) $850 \mathrm{~mm}$, max. body weight $24 \mathrm{~kg}$ ] have attracted the attention of fishermen and have sometimes fallen into the hands of scientific investigators. Such was the case when several somewhat damaged $T$. rhombus became available for morphological and anatomical studies, more than $130 \mathrm{yr}$ since the species' first description (as Sepioteuthis major) by Gray (1828, cited in Pfeffer 1912). 
Since the end of the 1950s, frequent occurrences of Thysanoteuthis rhombus near the Japanese coast have led to the development of a local fishery, which has enabled scientists to collect data on length-frequency distribution, seasonal migrations and aspects of $T$ rhombus biology (Nishimura 1966, Nazumi 1975, Misaki \& Okutani 1976, Osako \& Murata 1983).

An analysis of dynamics in the length-frequency distribution of Thysanoteuthis rhombus during the fishing season in the Japan Sea led Nazumi (1975) to suggest that this species' life cycle lasts $1 \mathrm{yr}$. His suggestion was based mainly on estimated monthly increments in T. rhombus ML: squids $>400 \mathrm{~mm}$ ML grew at a high rate, 90 to $120 \mathrm{~mm} \mathrm{ML} \mathrm{mo}^{-1}$.

The reproductive biology of Thysanoteuthis rhombus is little known. The structure of the sexual system has been analyzed mainly on the basis of immature specimens (Vigelius 1881, Brock 1882, Pfeffer 1912, Brug-gen 1962, Nazumi 1975). In our first communication on $T$. rhombus reproductive biology (Nigmatullin et al. 1991), we described the morphology and anatomy of the sexual system of mature adults and found that it was characterized by rather primitive features with respect to type of gonad attachment and structure of the hectocotylus and mostly secondary characters, including small oviducts and very large oviductal glands and ovary. Unusual sausage-like egg masses of $T$. rhombus were found relatively often in the surface layers of the tropical World Ocean. Some of them were incubated until hatching (review in Sabirov et al. 1987).

In the present paper, we estimate age and growth rates of Thysanoteuthis rhombus, based on statolith increment studies, and describe the main features of its reproductive biology.

\section{MATERIALS AND METHODS}

Collection of squids. Thysanoteuthis rhombus were collected in the tropical Atlantic (136 specimens; ML 60 to $850 \mathrm{~mm}$ ) and southeastern Pacific (26 specimens; ML 25 to $650 \mathrm{~mm}$ ) between 1975 and 1990 on board various Soviet research vessels as a by-catch during research surveys of the Atlantic orange-back squid Sthenoteuthis pteropus and Pacific jumbo squid Dosidicus gigas (Fig. 1).

Juveniles (25 to $100 \mathrm{~mm}$ ML) were captured using zoological trawls (horizontal openings ranging from 16 to $24 \mathrm{~m}$, vertical openings 6 to $8 \mathrm{~m}$ with $6 \mathrm{~mm}$ mesh) and an Isaacs-Kidd trawl at a depth ranging from 0 to $100 \mathrm{~m}$.

Immature and mature adults (100 to $850 \mathrm{~mm} \mathrm{ML}$ ) were caught mainly during light drift stations at night using handle rods equipped with jiggers of various kinds, as well as jigger lines, scoop nets with an opening diameter ranging from 20 to $100 \mathrm{~cm}$ and hand harpoons. In addition, 152 hauls were made between 5 and $150 \mathrm{~m}$ depth at night in the eastern equatorial Atlantic using 2 kinds of 'twin' trawls towed simultaneously by 2 medium-size vessels ( $800 \mathrm{GRT}$ ). The horizontal openings were 68 and $86 \mathrm{~m}$, the vertical openings were 10 and $15 \mathrm{~m}$, respectively, and the mesh size was $40 \mathrm{~mm}$. Forty Thysanoteuthis rhombus $(50$ to $800 \mathrm{~mm} \mathrm{ML)} \mathrm{were} \mathrm{analyzed} \mathrm{from} \mathrm{catches} \mathrm{of} \mathrm{twin}$ trawls.

Analysis of each Thysanoteuthis rhombus individual included measurements of dorsal ML (to the nearest millimeter) and BW (to the nearest gram), determination of sex and maturity stage, noting the presence of mating traces on the buccal membrane of females, and determining the degree of stomach fullness (after Zuev

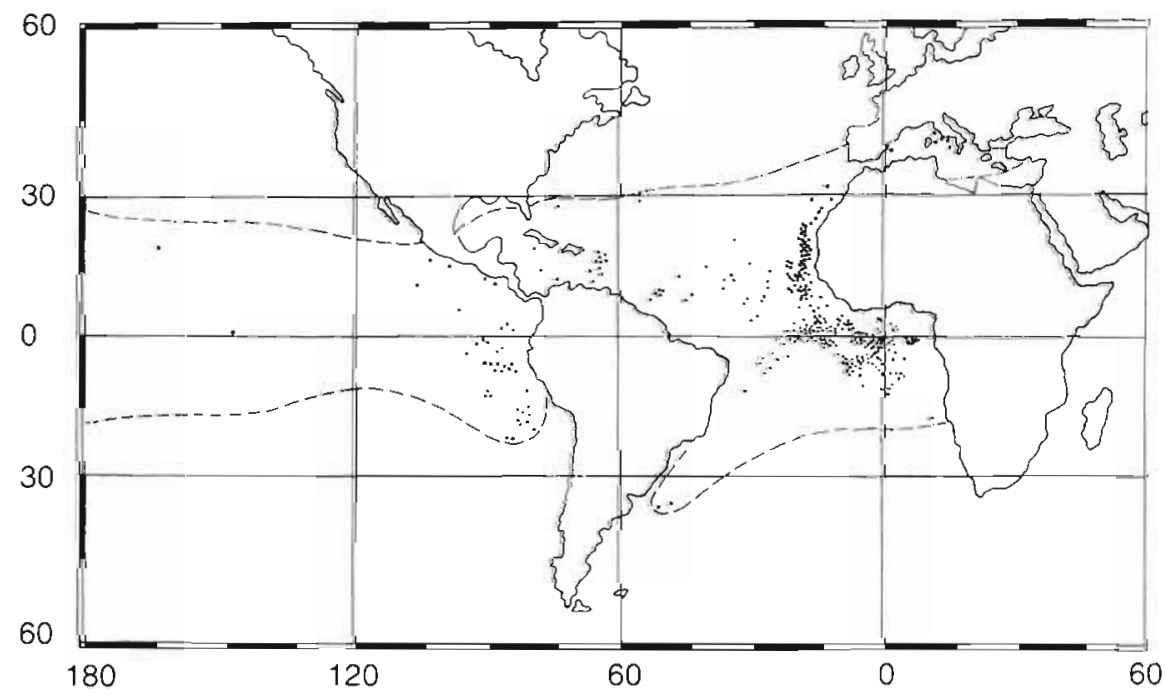

Fig. 1. Location of Thysanoteuthis rhombus samples collected in the tropical Atlantic and southeastern Pacific 
et al. 1985). To examine ontogenetic, sexual and geographical variations in $T$. rhombus morphology, 72 specimens were analyzed thoroughly according to the scheme of morphometrics proposed by Roper \& Voss (1983).

Statolith analysis. Statoliths were extracted from 72 specimens of Thysanoteuthis rhombus (25 to $805 \mathrm{~mm}$ ML) captured in the eastern tropical Atlantic and southeastern Pacific between 1982 and 1988. Statoliths were stored in $96 \%$ ethyl alcohol and processed in the laboratory. Terminology and measurement of statoliths followed Clarke (1978). Statoliths were ground on both sides on wet waterproof sandpaper (1000 grit) and embedded into Canada balsam. Patterns of statolith microstructure were examined using a light microscope (BIOLAM R-14) under 400× magnification. Growth increments were counted from the nucleus to the edge of the statolith dorsal dome using an ocular micrometer (as described in Dawe \& Natsukari 1991).

In this study, it was impossible to validate the periodicity of increment formation in Thysanoteuthis rhombus statoliths. However, in structure and width of increments, $T$. rhombus statoliths resemble those of squid species for which validations have been obtained (review in Arkhipkin 1991). Only daily periodicity of statolith growth increments has been observed in squids of 3 large families: Loliginidae (Loligo opalescens, Hixon \& Villoch 1984; Alloteuthis subulata, Lipinski 1986; Sepioteuthis lessoniana, Jackson 1990), Ommastrephidae (Illex illecebrosus, Dawe et al. 1985; Todarodes pacificus, Nakamura \& Sakurai 1991) and Enoploteuthidae (Abralia trigonura, Bigelow 1992) Considering these points we assume that the hypothesis ' 1 increment per day' is also true for $T$ rhombus. The total number of growth increments within a statolith was considered to be the age of the squid in days. Hatching dates were back-calculated.

For construction of a group growth curves, we tested the fit of our ML and BW data to one of several sigmoidal curves (logistic, Gompertz and von Bertalanffy) using the iterative nonlinear least squares method. Using the formula for the best-fitted curve (logistic in our case), we calculated values ML and BW values for each $15 \mathrm{~d}$ interval starting at age $60 \mathrm{~d}$. Daily growth rates (DGR, $\mathrm{mm} \mathrm{d}^{-1}$ or $\mathrm{g} \mathrm{d}^{-1}$ ) and instantaneous growth rate (G) were calculated after Ricker (1958):

$$
\begin{aligned}
& \mathrm{DGR}=\left(\mathrm{W}_{2}-\mathrm{W}_{1}\right) / \mathrm{T} \\
& \mathrm{G}=\left(\ln \mathrm{W}_{2}-\ln \mathrm{W}_{1}\right) / \mathrm{T}
\end{aligned}
$$

where $W_{1}$ and $W_{2}$ are $M L$ or $B W$ at the beginning and end of the time interval $(T=15 \mathrm{~d})$.

Analysis of the sexual system. The sexual systems of 162 Thysanoteuthis rhombus ( 150 to $850 \mathrm{~mm} \mathrm{ML}$ ) were extracted during analysis on board ship and stored in $6 \%$ formaldehyde for further analysis in the laboratory.
The ovaries, oviducts, and oviductal and nidamental glands in females and the testes, spermatophoric glands and Needham sacs in males were measured and weighed to the nearest $0.1 \mathrm{~g}$ after fixation. For determination of oocyte number in the ovary, we took 3 subsamples $(50 \mathrm{mg}$ ) from the ovary surface, from the ovary core and from the intermediate layer. To avoid the effect of preservation, when the oocytes were not perfectly symmetrical we measured the diameters of oocytes with an ocular micrometer placed in a horizontal position (Clarck 1934). The average diameter of each phase of oocytes was estimated based on 50 oocytes of each female. Six oocyte phases were distinguished according to Burukovskii et al. (1977). Oocyte number in the oviducts was assessed from counts of three $200 \mathrm{mg}$ subsamples.

The gonadosomatic index (GSI) and maturity coefficient (MI) were calculated for each specimen as

$$
\begin{aligned}
& \mathrm{GSI}=(\mathrm{GW} / \mathrm{BW}) \times 100 \\
& \mathrm{MI}=(\mathrm{SSW} / \mathrm{BW}) \times 100
\end{aligned}
$$

where GW is gonad weight, SSW is total weight of the sexual system and BW is body weight of the squid excluding weight of the stomach contents.

Potential fecundity (PF) was calculated as the sum of total oocyte number in the ovary and total egg number in the oviducts. Relative fecundity (RF, number of oocytes per gram) was estimated as

$$
\mathrm{RF}=\mathrm{PF} / \mathrm{BW}
$$

In addition, we estimated the actual realized fecundity (ARF) as the total number of vitelline oocytes in the ovary and eggs in the oviducts, and relative actual realized fecundity (RARF) as

\section{$\mathrm{RARF}=\mathrm{ARF} / \mathrm{BW}$}

The scheme used for analyzing the male sexual system is described in Nigmatullin et al. (1991). Number of spermatophores was determined after dissection of the spermatophoric gland and Needham sac. We assumed the total number of spermatophores both forming within the spermatophoric gland and accumulating within the Needham sac to be the ARF for males.

\section{RESULTS}

\section{Age and growth}

Statolith morphology

The statolith of adults is elongate (Fig. 2C). The dorsal dome is developed and smooth. The lateral dome is not well-developed, and is prolonged and smooth. The rastral angle is approximately $90^{\circ}$. The rostrum is 


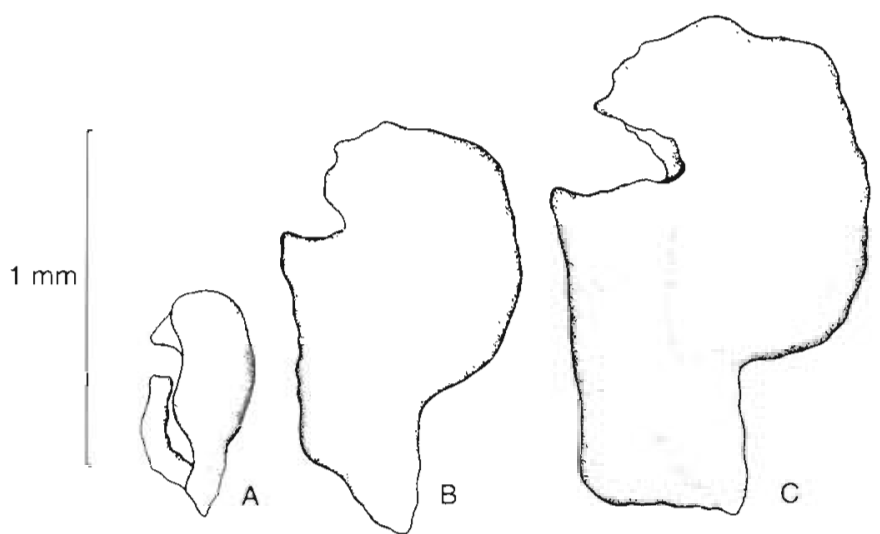

Fig. 2. Thysanoteuthis rhombus. Statolith morphology, posterior views. (A) Juvenile, $25 \mathrm{~mm}$ mantle length (ML), (B) immature female, $320 \mathrm{~mm} \mathrm{ML}$, (C) mature female, $770 \mathrm{~mm} \mathrm{ML}$.

short, 27 to $30 \%$ of total statolith length (STL). The dorsal spur is well-defined, arising out of the dorsal dome. The wing is broad and thick, its lower part curved at an angle of 70 to $80^{\circ}$ to the main plane of the statolith. The statolith width is about $60 \%$ of STL.

Statoliths of immature squid (ML 200 to $400 \mathrm{~mm}$ ) were already at stage $\mathrm{V}$ (the 'definite' stage) (Arkhipkin \& Murzov 1986), without upper and lower fissures. However, they are distinguished from those of large adults by their obtuse rostral angle and relatively narrow wing (Fig. 2B).

Statoliths of early juveniles (ML $27 \mathrm{~mm}$ ) were characterized by a narrow wing, attaching to the lower part of the statolith body, and slightly curved rostrum (Fig. 2A).

\section{Statolith microstructure}

On the ground surface of a Thysanoteuthis rhombus statolith, 4 main growth zones could be distinguished (Fig. 3A). The nucleus lay under the statolith spur, was oval in shape and had a maximum diameter of $26 \mu \mathrm{m}(\mathrm{SD}=2.82, \mathrm{n}=72$ ) and minimum diameter $18 \mu \mathrm{m}$ ( $\mathrm{SD}=2.45, \mathrm{n}=72$ ). A dark stone-like concretion lay in the focus of the nucleus (Fig. 3B). The postnuclear zone was translucent, with growth increments that became wider in the direction of the dorsal dome and narrowed rapidly in the direction of the lateral dome (Fig. 3B). The total number of growth increments in the postnuclear zone varied from 21 to 28 (mean $=25.2, \mathrm{SD}=2.12$ ). Their maximum width was 4.5 to $5 \mu \mathrm{m}$. Within the postnuclear zone, there were several ( 4 to 6 ) checks with 4 to 7 increments between them (Fig. 3B). Usually we could observe a prominent check between the postnuclear and dark zones. The dark zone was distinct and appeared slightly brown in transmitted light. Growth increments in the dark zone were wide $(4.8$ to $5.7 \mu \mathrm{m})$ and numerous (56 to 79 ; mean $=67, \mathrm{SD}=4.5)($ Fig 3C) , The width of growth increments gradually decreased in the transluscent peripheral zone, from 2.2-2.4 $\mu \mathrm{m}$ in the midportion to $1.0-1.1 \mu \mathrm{m}$ near the statolith edge (Fig. 3D). Stress marks were not observed in the outer portion of the peripheral zone in the statoliths of large mature squid.

\section{Statolith growth}

Statoliths of early juveniles (25 to $27 \mathrm{~mm}$ ML) were rather large, with STL $0.67 \mathrm{~mm}$ (2.48 to $2.68 \% \mathrm{ML})$. However, they grew very slowly during ontogenesis and increased only 2.5 times in length by the age of $330 \mathrm{~d}$ (1.55 $\mathrm{mm}$ in a mature male of $770 \mathrm{~mm} \mathrm{ML}$ ) (Fig. 4). Allometric growth of STL versus ML was strongly negative, with a low allometric coefficient (Fig. 5, Table 1).

\section{Age and growth of squid}

In our samples, the minimum age $(60 \mathrm{~d})$ was observed in early juveniles of 25 and $27 \mathrm{~mm} \mathrm{ML}$, and the maximum ages in a mature female of $750 \mathrm{~mm} \mathrm{ML}$ (305 d) and a mature male of $770 \mathrm{~mm} \mathrm{ML} \mathrm{(309} \mathrm{d).} \mathrm{The}$ largest specimen (mature male, $805 \mathrm{~mm} \mathrm{ML}$ ) had 288 growth increments within its statoliths.

Sexual dimorphism in the growth of Thysanoteuthis rhombus was not apparent (Figs. 6 \& 7). Data on growth of both ML and BW during ontogenesis was best described by logistic growth curves; the parameters for these curves are shown in Table 1 . These data show that $T$. rhombus is one of the fastest-growing squids. Individuals attained $90 \mathrm{~mm} \mathrm{ML}$ at age $90 \mathrm{~d}$, and $590 \mathrm{~mm} \mathrm{ML}$ at age $240 \mathrm{~d}$ (Fig. 6). At age $300 \mathrm{~d}$, they reached 750 to $800 \mathrm{~mm} \mathrm{ML}$ and up to 17 to $17.5 \mathrm{~kg} \mathrm{BW}$ (Fig. 7). However, growth rates were not uniform (Figs. 8 \& 9). Daily rates of ML growth were low in early juveniles (1.2 to $\left.1.5 \mathrm{~mm} \mathrm{~d}^{-i}\right)$, but they quickly attained maximum values by age 150 to $180 \mathrm{~d}(4.6 \mathrm{~mm}$ $\left.\mathrm{d}^{-1}\right)$, then decreased to $0.97 \mathrm{~mm} \mathrm{~d}^{-1}$ at age $300 \mathrm{~d}$ (Fig. 8). Daily rates of BW growth showed a similar tendency, but with maximum values (177 $\left.\mathrm{g} \mathrm{d}^{-1}\right)$ occurring at age $240 \mathrm{~d}$. By age $300 \mathrm{~d}$, growth decreased to $51 \mathrm{~g} \mathrm{~d}^{-1}$.

The instantaneous growth rate, $\mathrm{G}$, of ML was maximum in early juveniles $(0.022$ to 0.025$)$, gradually decreasing to 0.0012 by age $300 \mathrm{~d}$. In contrast, $\mathrm{G}$ of BW was high and almost constant from age 60 to 150 d (between 0.037 and 0.039). After that it decreased sharply to 0.003 at age $300 \mathrm{~d}$. 

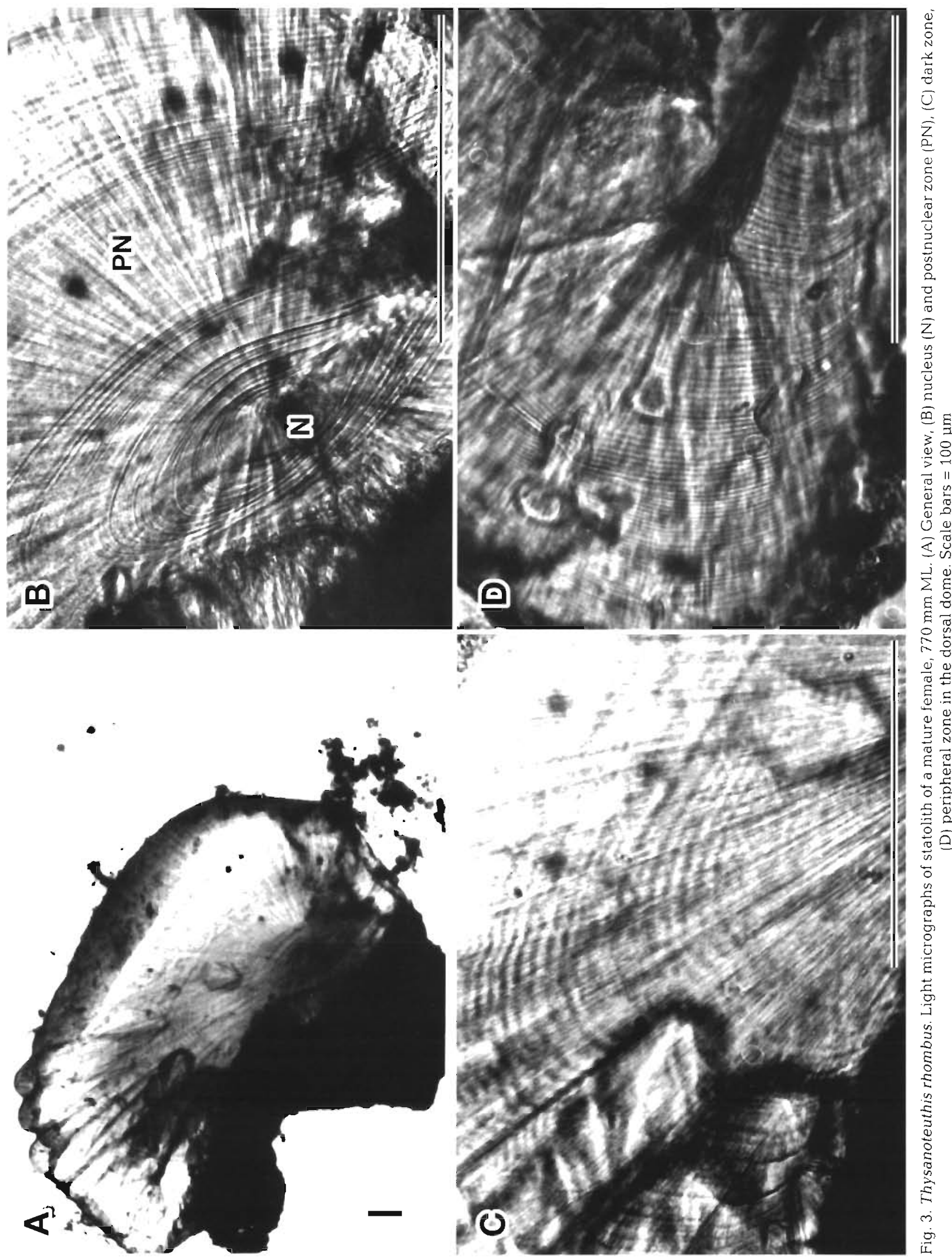

要 


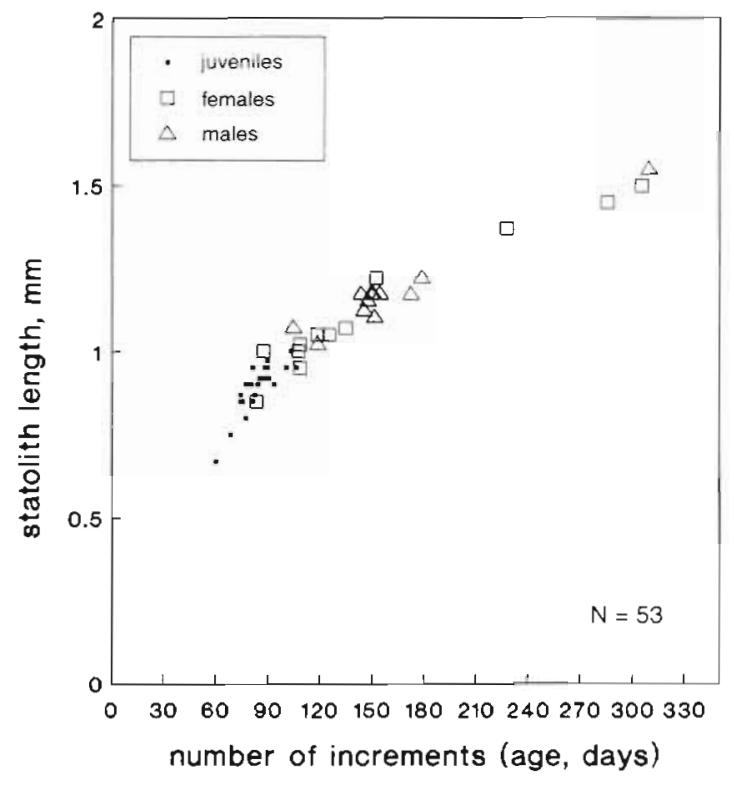

Fig. 4. Thysanoteuthis rhombus. Relationship between number of increments in statoliths and statolith length

\section{Reproductive biology}

Size and age of maturation

Sex may be distinguished visually in squids greater than 100 to $120 \mathrm{~mm}$ in ML by the appearance of primordial nidamental glands on the coelomic coverings of females, and a primordial spermatophoric gland on the coelomic coverings of males. Calculated ages of these individuals ranged from 100 to $110 \mathrm{~d}$. Physiological maturation (i.e. maturation of the gonad to maturity

Table 1. Thysanoteuthis rhombus. Parameters of the allometric growth curve STL $=a \mathrm{ML}^{b}$ based on total statolith length (STL, mm) at mantle length ( $\mathrm{ML}, \mathrm{mm}$ ) relationships; and the logistic growth curve $Y(t)=K /\{1+[(K-Y(0) / Y(0)] \exp (-r t)\}$ based on mantle length $(\mathrm{ML}, \mathrm{mm})$ or body weight $(\mathrm{BW}, \mathrm{g})$ at age $(t)$ relationships

\begin{tabular}{|c|c|c|c|}
\hline Parameter & Estimate & $\begin{array}{c}\text { Asymptotic } \\
\text { standard error }\end{array}$ & $\mathrm{R}^{2}$ \\
\hline \multicolumn{4}{|c|}{ Allometric growth curve: STL versus ML } \\
\hline a & 0.3192 & 0.03411 & \multirow[t]{2}{*}{0.79} \\
\hline$b$ & 0.2304 & 0.02045 & \\
\hline \multicolumn{4}{|c|}{ Logistic growth curve: ML versus age $(t)$} \\
\hline I & 0.02288 & 0.001009 & \multirow[t]{3}{*}{0.9761} \\
\hline$K$ & 812 & 20.039 & \\
\hline$Y(0)$ & 13.22 & 1.704 & \\
\hline \multicolumn{4}{|c|}{ Logistic growth curve: $B W$ versus age $(t)$} \\
\hline$r$ & 0.03868 & 0.002815 & \multirow[t]{3}{*}{0.9916} \\
\hline K & 19020 & 517.8 & \\
\hline$Y(0)$ & 1.577 & 0.9711 & \\
\hline
\end{tabular}

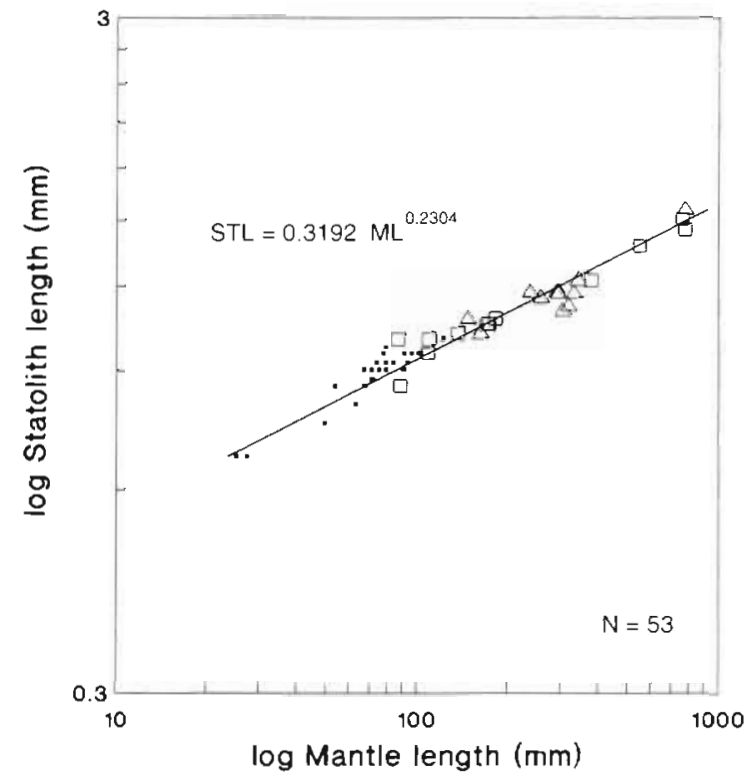

Fig. 5. Thysanoteuthis rhombus. Allometric growth of statolith length versus mantle length. Symbols as in Fig. 4

stage III) was observed in males that had attained 250 to $350 \mathrm{~mm} \mathrm{ML}$ (calculated age 150 to $170 \mathrm{~d}$ ). In females, physiological maturation occurred later, at 500 to $620 \mathrm{~mm} \mathrm{ML}$ (calculated age 215 to $240 \mathrm{~d}$ ). Fig. 6 and Table 2 show the sizes and ages at which males and females reached functional maturity (stage V). The

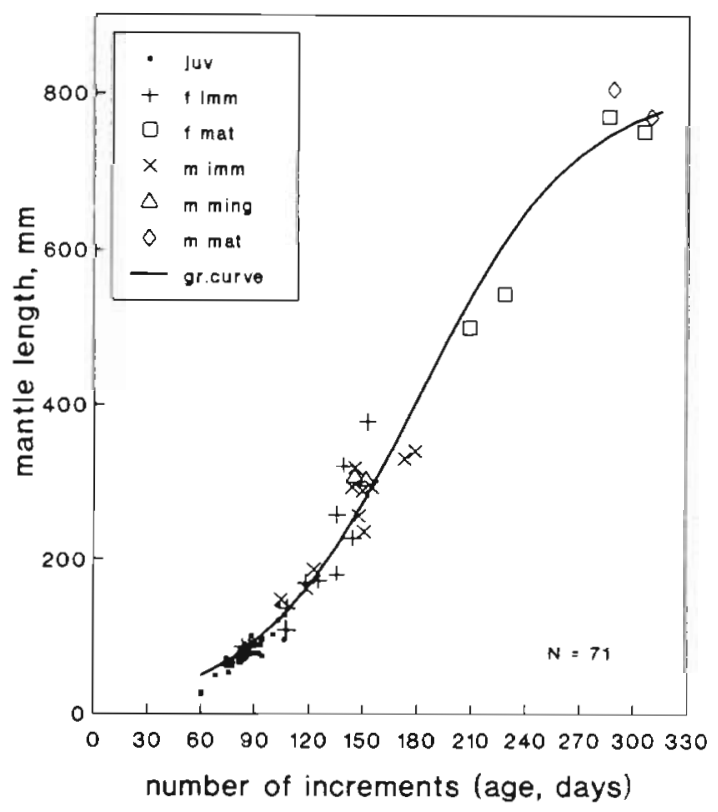

Fig. 6. Thysanoteuthis rhombus. Relationship between number of increments in statoliths and mantle length, showing fitted logistic growth curve (parameters in Table 1). juv: juveniles; m: males; f: females; imm: immature; ming: maturing; mat: mature 


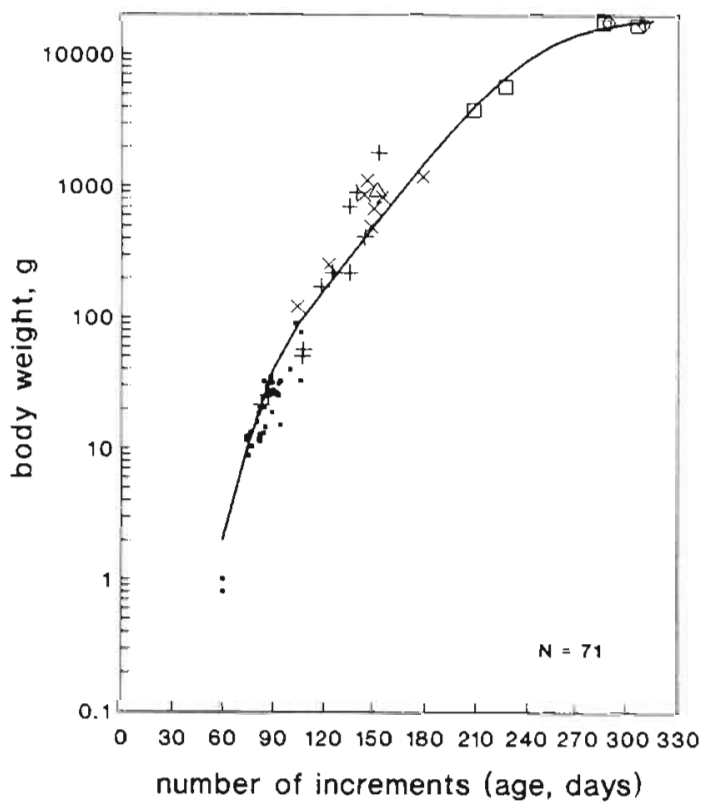

Fig. 7. Thysanoteuthis rhombus. Relationship between number of increments in statoliths and body weight, showing fitted logistic growth curve (parameters in Table 1). Symbols as in Fig. 6

smallest mature male was $390 \mathrm{~mm} \mathrm{ML}$, whereas maturity in females began at $520 \mathrm{~mm}$ ML (age was not determined). The bulk of males were mature at 400 to $450 \mathrm{~mm} \mathrm{ML}$ (calculated age 190 to $200 \mathrm{~d}$ ) and of females at 550 to $650 \mathrm{~mm}$ ML (calculated age 230 to $250 \mathrm{~d})$. All males larger than $450 \mathrm{~mm}$ and females larger than $650 \mathrm{~mm}$ were mature.

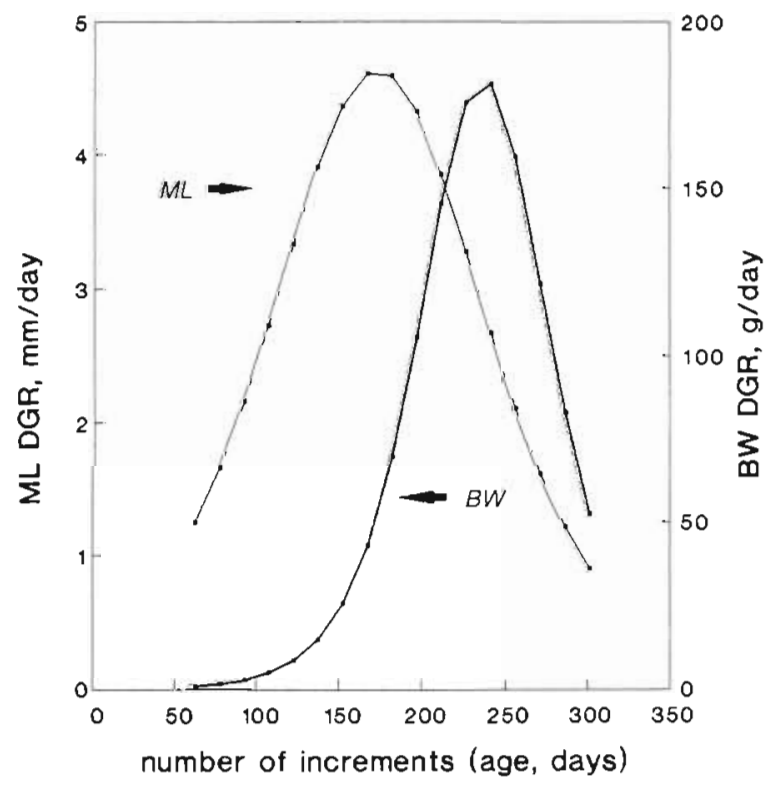

Fig. 8. Thysanoteuthis rhombus. Daily growth rates (DGR) of mantle length (ML) and body weight (BW) versus number of increments in statoliths

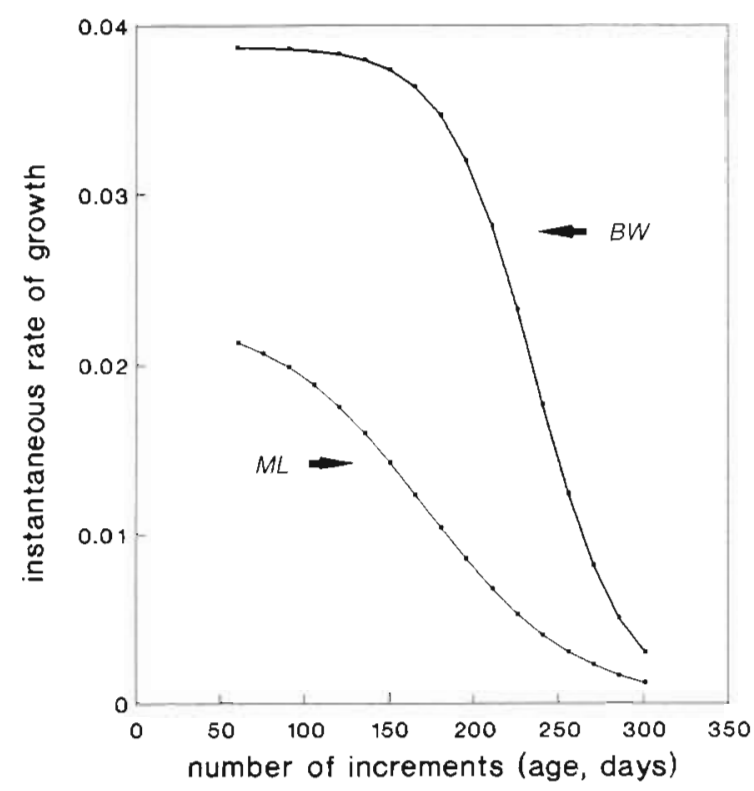

Fig. 9. Thysanoteuthis rhombus. Instantaneous rate of growth of mantle length ( $\mathrm{ML}$ ) and body weight (BW) versus number of increments in statoliths

Female sexual system

In females of 100 to $150 \mathrm{~mm} \mathrm{ML}$, a pair of nidamental glands appeared as narrow and long stripes on the surface of the sexual coelom. The length of the nidamental glands in these individuals was

Table 2. Thysanoteuthis rhombus. Dynamics of maturation of males and females; values are numbers of individuals in each maturity stage

\begin{tabular}{|c|c|c|c|c|c|c|c|c|c|c|}
\hline \multirow{2}{*}{$\begin{array}{l}\text { Mantle length } \\
\text { interval (mm) }\end{array}$} & \multicolumn{5}{|c|}{ Females } & \multicolumn{5}{|c|}{ Males } \\
\hline & I & II & III & IV & V & I & $1 \mathrm{II}$ & III & IV & V \\
\hline \multicolumn{11}{|l|}{0} \\
\hline 100 & 9 & & & & & 11 & & & & \\
\hline 150 & 13 & & & & & 9 & & & & \\
\hline 200 & 9 & & & & & 7 & 1 & & & \\
\hline 250 & 8 & 3 & & & & 5 & 1 & 1 & & \\
\hline 300 & 6 & 7 & & & & 3 & 5 & 1 & & \\
\hline 350 & - & 4 & & & & 3 & - & 1 & - & 1 \\
\hline 400 & 2 & 3 & & & & 1 & 2 & - & 2 & 1 \\
\hline 450 & 2 & & & & & & & & & 3 \\
\hline 500 & & & & & & & & & & 1 \\
\hline 550 & & & & & 1 & & & & & 3 \\
\hline 600 & & 1 & 3 & 1 & - & & & & & 4 \\
\hline 650 & & & & & 4 & & & & & 1 \\
\hline 700 & & & & & 3 & & & & & 3 \\
\hline 750 & & & & & 8 & & & & & 3 \\
\hline 800 & & & & & 1 & & & & & 1 \\
\hline \multicolumn{11}{|l|}{850} \\
\hline Total & 49 & 18 & 3 & 1 & 17 & 39 & 9 & 3 & 2 & 21 \\
\hline Grand total & & & 88 & & & & & 74 & & \\
\hline
\end{tabular}




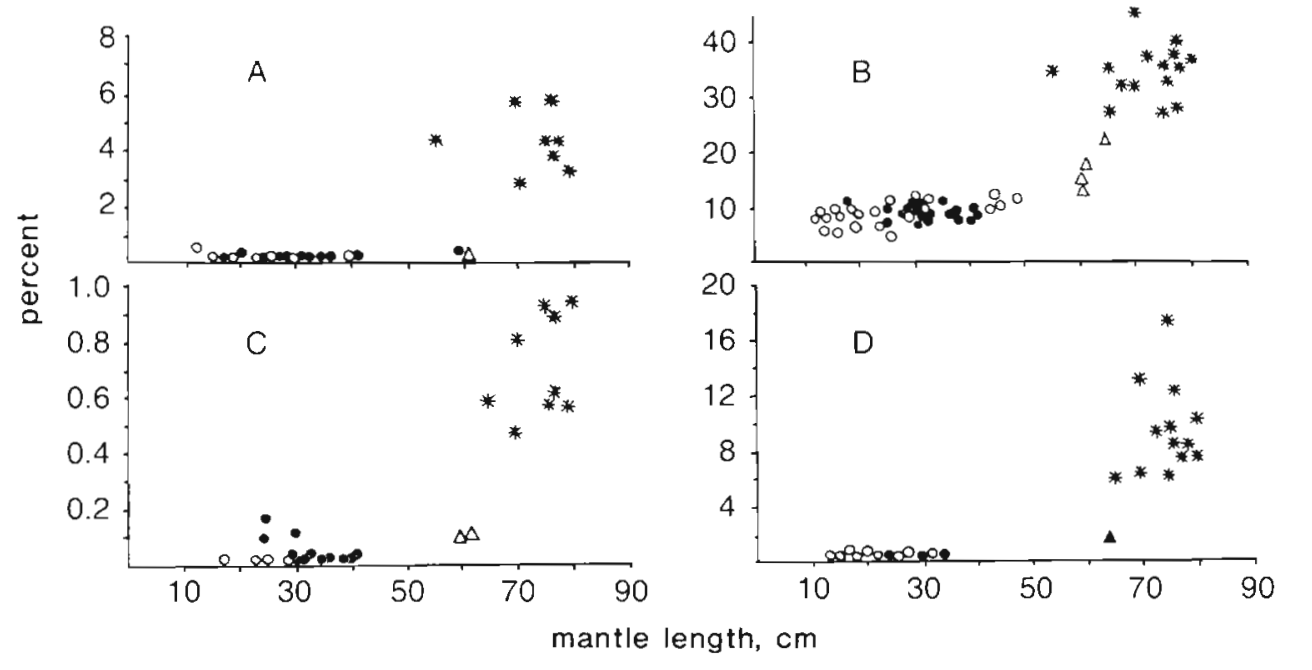

$$
\begin{aligned}
& \text { - I - II } \Delta \text { III } \\
& \text { 4 IV * V }
\end{aligned}
$$

Fig. 10. Thysanoteuthis rhombus. Ontogenetic variability of various indices of the female sexual system. (A) Gonadosomatic index, (B) ratio of nidamental gland length to mantle length, (C) ratio of nidamental gland weight to body weight, (D) maturity coefficient; I to $V$ : maturity stages

$<10 \mathrm{~mm}$ ( 8 to $9 \% \mathrm{ML}$ ); their weight was about $0.05 \mathrm{~g}$ (0.001\% BW) (Fig. 10B, C). Length of the nidamental glands at maturity stages I and II was 6 to $11 \% \mathrm{ML}$; at stage III, 13 to $17 \% \mathrm{ML}$; at stage IV, $21 \% \mathrm{ML}$; and at stage V, 26 to $44 \%$ ML. Maximum development of the nidamental glands was revealed in females with the highest maturity coefficient (MC).

$\mathrm{MC}$ increased with the progress of both ML and maturity stage, from $0.1 \% \mathrm{BW}$ at maturity stage I to $1.5 \% \mathrm{BW}$ at maturity stage IV. Mature females had a higher MC, up to between 6 and $17 \%$ BW (Fig. 10D).

Ovary shape did not change during ontogeny, but ovary relative weight (GSI) increased considerably (Fig. 10A). The ovary of females at maturity stage IV was pale, without a mosaic structure after fixation and storage in formaldehyde. At maturity stage $V$, the ovary was yellowish-brown, with a mosaic structure.

In the ovary of mature females, oocytes were at various stages of ripening, exhibiting asynchrony in their development. It was possible to distinguish 6 size groups of oocytes (Fig. 11, Table 3) that corresponded to the following stages of oocyte development (after Burukovskii et al. 1977): Size group I corresponded to the second phase of provitellogenesis ('primary follicle'), oocytes were polygonal, and the centrally situated nucleus was oval and large. Group II corresponded to the third phase of provitellogenesis ('simple follicle'), oocytes were either oval or goblet-shaped, and the cytoplasm volume was increased in comparison to the preceding size group. Group III obviously corresponded to the intercalary period of oocyte development ('complicated follicle'); oocytes were leaf-like, of dark color, with numerous shallow longitudinal grooves together with follicle cells that protruded into the grooves. The nucleus was not visible. Group IV corresponded to the first and second phases of trophoplasmatic growth ('vacuolization and vitelline accumulation'). Oocytes were covered with
Fig. 11. Thysanoteuthis rhombus. Size groups of oocytes within the ovary. (A) Size group I, (B) group II, (C) group III, (D) group IV, (E) group V, (F) group VI, (G) blood vessel with various size groups of oocytes 


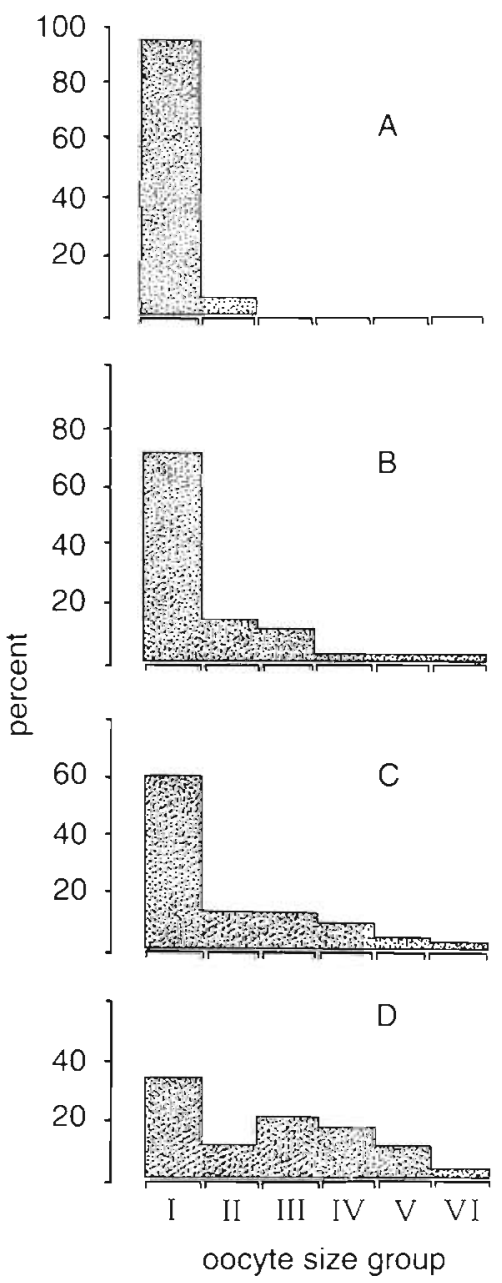

Fig. 12. Thysanoteuthis rhombus. Frequency distribution of different size groups of oocytes within ovary of: (A) immature female of $330 \mathrm{~mm} \mathrm{ML}$, (B) maturing female of $640 \mathrm{~mm} \mathrm{ML}$ $(\mathrm{MC})=1.6),(\mathrm{C})$ mature female of $730 \mathrm{~mm} \mathrm{ML}(\mathrm{MC}=9.0)$, (D) mature female of $703 \mathrm{~mm} \mathrm{ML}(\mathrm{MC}=12.9)$

reticulate grooves, and dark in color. Group V corresponded to the third phase of trophoplasmatic growth ('expulsion of follicles'); oocytes were rounded and yellow, the reticulate grooves having almost disappeared. Group VI corresponded to the fourth phase of

Table 3. Thysanoteuthis rhombus. Diameter of different size groups of oocytes from the ovary of females

\begin{tabular}{|lccc|}
\hline Size group & \multicolumn{3}{c|}{$\begin{array}{c}\text { Diameter (mm) } \\
\text { Mean }\end{array}$} \\
\hline I & Range & SD \\
II & $0.07-0.25$ & 0.15 & 0.032 \\
III & $0.3-0.5$ & 0.19 & 0.052 \\
IV & $0.5-0.15$ & 0.38 & 0.047 \\
V & $1.05-1.8$ & 0.94 & 0.121 \\
VI & $1.5-1.8$ & 1.65 & 0.093 \\
& & & 0.046 \\
\hline
\end{tabular}

the trophoplasmatic growth ('ripe oocyte'). Oocytes had a smooth surface and were oval and crimsonviolet.

The proportion of oocytes in different size groups changed as the sexual system developed (Fig. 12). In immature females, oocytes of size group I dominated $(95 \%)$ : the remaining ones were of size group II. In maturing females, ripe oocytes were practically absent. In mature females, the relative numbers of oocytes in groups II and III were almost the same (10 to $15 \%$ ), whereas the proportion of oocytes in groups IV and V increased with increasing MC. Females with maximum $\mathrm{MC}$ had oocytes of size groups IV and $\mathrm{V}$ in almost equal proportion to those of size groups II and III. The relative quantity of ripe oocytes in the ovaries was always low $(<1 \%)$, because they were immediately transferred into the oviducts after their extrusion into the coelom.

Individual PF varied considerably (Table 4): from 2.3-5 million oocytes in immature females to $2.7-4.8$ million oocytes in maturing and mature females. The female with maximum $\mathrm{MC}$ had the lowest PF (2.4 million). ARF increased from 300000 vitelline oocytes in females with $\mathrm{MC}=5.9 \% \mathrm{ML}$ to 860000 in females with $\mathrm{MC}=12.9 \%$.

\section{Male sexual system}

The testis in males $<150 \mathrm{~mm}$ is a narrow, long strip hanging from the mesentery of the sexual coelom. In immature males $<400 \mathrm{~mm} \mathrm{ML}$, the length of the testis varied significantly from $3-4$ to $18-20 \% \mathrm{ML}$. In larger males, the relative length of the testis stabilized and became more or less uniform at 10 to $16 \% \mathrm{ML}$ (Fig. 13A). In mature males, the testis became broader and more robust in shape, like an elongate oval. Weight of the testis increased from 0.01-0.1 to $0.2-0.6 \%$ BW (Fig. 13B). The same increase was observed in the weight of the spermatophoric complex of organs (Fig. 13C). MC increased with the progressing maturity state of males, with values of $0.15 \% \mathrm{BW}$ in immature squid, $0.3 \% \mathrm{BW}$ in maturing and 0.9 to $1.2 \%$ BW in mature males (Fig. 13D).

Formation of the spermatophores in different parts of the spermatophoric gland (SG) is similar to that in other squid and cuttlefish (Blanquaert 1925). Spermatozoa enter into the first section of the SG from the spermaduct and mix with its gelatinous secretions. The frequency of occurrence of developing spermatophores (\% of the sampled male squid that contained spermatophores in a given section of their $\mathrm{SG}$ ) varied in different sections of the SG, from $66 \%$ in sections II, III and IV, to $17 \%$ in section $\mathrm{V}$, and $100 \%$ in section $\mathrm{VI}$, as well as $34 \%$ in the spermatophoric duct. In sections II to IV, there occurs a 
gradual and complete formation of all parts of the spermatophores from the sperm mass to the external coverings. In section $V$ of the $\mathrm{SG}$ the spermatophore turns and quickly moves into section VI, where its coverings become resilient as a result of dehydration.

The spermatophores of Thysanoteuthis rhombus are large, ranging from $60-70 \mathrm{~mm}$ in males of $420 \mathrm{~mm} \mathrm{ML}$ to $95-100 \mathrm{~mm}$ in males of $850 \mathrm{~mm} \mathrm{ML}$, the volume of their seminal reservoirs varying from $0.12-0.13$ to $0.44-0.5 \mathrm{~cm}^{3}$, respectively. Thus, the total volume of seminal fluid in all spermatophores of a single male may reach 2.4 to $9 \mathrm{~cm}^{3}$.

In developing spermatophores, the cement body is 1.2 to 2 times larger and the ejaculatory tube is 1.5 to 2 times longer than those of ripe spermatophores. These parts of the spermatophore attain definite sizes when the spermatophore exits section VI of the SG.

The number of spermatophores located in different parts of the SG does not depend on the length of males. Usually, in both the SG and the spermatophoric duct there were 3 developing spermatophores (in $66 \%$ of males); in rare cases there were 2 or 4 spermatophores (17 and $17 \%$, respectively). The number of developing spermatophores also does not depend on the total number of ripe spermatophores in the Needham sac: in a male of $695 \mathrm{~mm}$ ML there were 15 spermatophores in the Needham sac and 3 developing spermatophores in the $\mathrm{SG}$; in a male of $850 \mathrm{~mm} \mathrm{ML}, 11$ and 4 , respectively; in a male of $770 \mathrm{~mm} \mathrm{ML}, 6$ and $3 ;$ in a male of $420 \mathrm{~mm} \mathrm{ML}, 10$ and 3 .
Table 4. Thysanoteuthis rhombus. Characteristics (in mm and g) of the sexual system of 1 maturing and 6 mature females farranged in order of increasing maturity coefficient, $\mathrm{MC}$, indicated in bold). $\mathrm{NGL}_{\text {, nidamental gland }}$ length; OW, weight of ovary; OVW, weight of oviducts; OGW, weight of oviductal glands; SSW, total weight of sexual system; OVN, number of eggs in oviducts $\left(\times 10^{3}\right)$; $\mathrm{PF}$, potential fecundity $\left(\times 10^{6}\right.$ oocytes $)$; $R F$, relative potential fecundity (oocytes $\mathrm{g}^{-1} \mathrm{BW}$ ); ARF, actual realized fecundity $\left(\times 10^{6}\right.$ oocytes); RARF, relative actual realized fecundity (oocytes $\mathrm{g}^{-1} \mathrm{BW}$ ); GSI, gonadosomatic index (\%); MC, maturity coefficient (\%)

\begin{tabular}{|c|c|c|c|c|c|c|c|}
\hline \multirow[t]{2}{*}{ Feature } & \multirow[t]{2}{*}{ Maturing female } & \multicolumn{6}{|c|}{ Mature females } \\
\hline & & 1 & 2 & 3 & 4 & 5 & 6 \\
\hline Mantle length $(\mathrm{mm})$ & 640 & 650 & 686 & 730 & 751 & 800 & 703 \\
\hline Body weight $(\mathrm{kg})$ & 9.1 & 10.4 & 12.3 & 16.8 & 10.5 & 13.9 & 12.5 \\
\hline NGL & 140 & 220 & 212 & 260 & 235 & 280 & 308 \\
\hline OW & 25.6 & 225 & 255 & 590 & 435 & 530 & 525 \\
\hline OVW & 20.0 & 22.0 & 27.5 & 84.5 & 64.0 & 65.0 & 150 \\
\hline OGW & 70 & 270 & 300 & 700 & 376 & 650 & 740 \\
\hline SSW & 146 & 615 & 752 & 1509 & 971 & 1375 & 1590 \\
\hline OVN & - & 22 & 25 & 74 & 72 & 62 & 140 \\
\hline PF & 2.7 & 4.8 & 3.9 & 4.9 & 3.1 & 3.5 & 2.4 \\
\hline $\mathrm{RF}$ & 291 & 457 & 316 & 292 & 299 & 251 & 194 \\
\hline ARF & 0.036 & 0.3 & 0.325 & 0.7 & 0.64 & 0.7 & 0.86 \\
\hline RARF & 3.8 & 28.5 & 26.5 & 42.0 & 59.7 & 50.3 & 69.7 \\
\hline GSI & 0.3 & 2.0 & 2.0 & 3.5 & 4.2 & 3.8 & 4.3 \\
\hline $\mathrm{MC}$ & 1.6 & 5.9 & 6.1 & 9.0 & 9.3 & 9.9 & 12.9 \\
\hline
\end{tabular}

The total number of spermatophores in the Needham sac varied from 5 to 10 , commonly 8 or 9 . Therefore, the total number of spermatophores located in both the SG and the Needham sac is low and does not exceed 15 to 17. Probably, males form 15 to 20 spermatophores between any 2 matings. This assumption is supported by the total number of spermatangues found on the buccal membrane of females (not more than 20), which are the traces of the previous copulation.

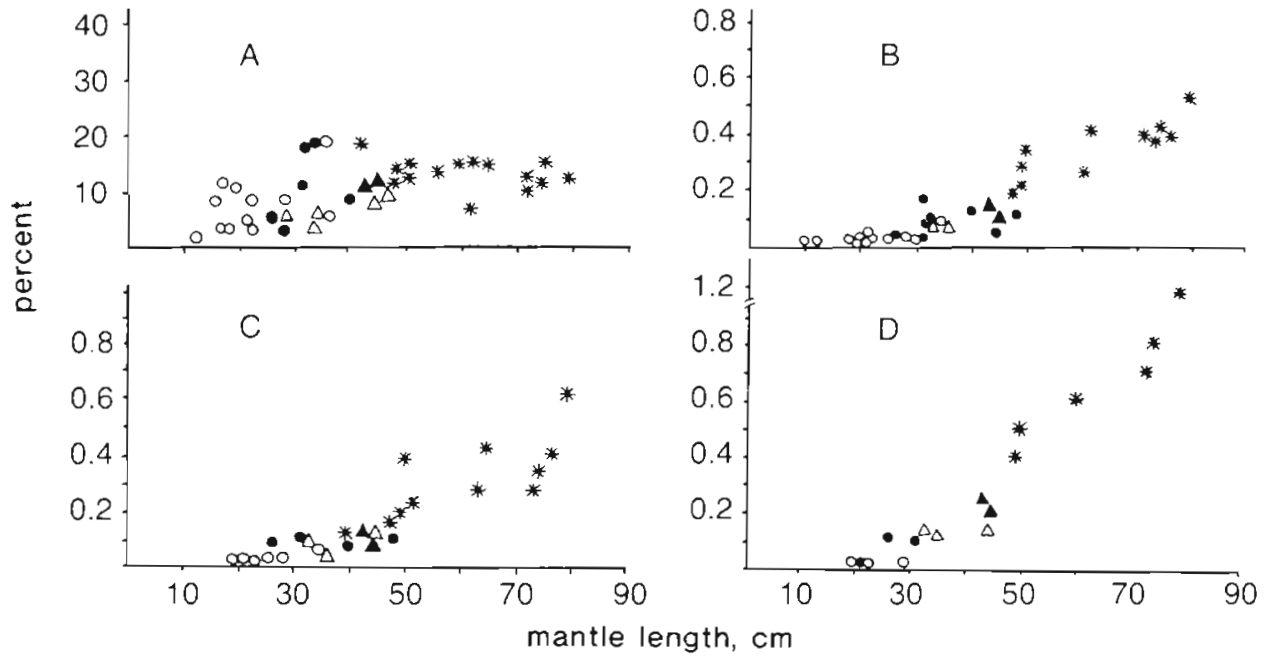

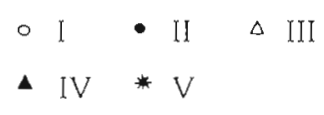

Fig. 13. Thysanoteuthis rhombus. Ontogenetic variability of vanous indices of the male sexual system. (A) Ratio of testis length to mantle length, (B) gonadoso. matic index, (C) ratio of total spermatophoric gland and Needham sac weights to body weight, (D) maturity coefficient. I to V: maturity stages 


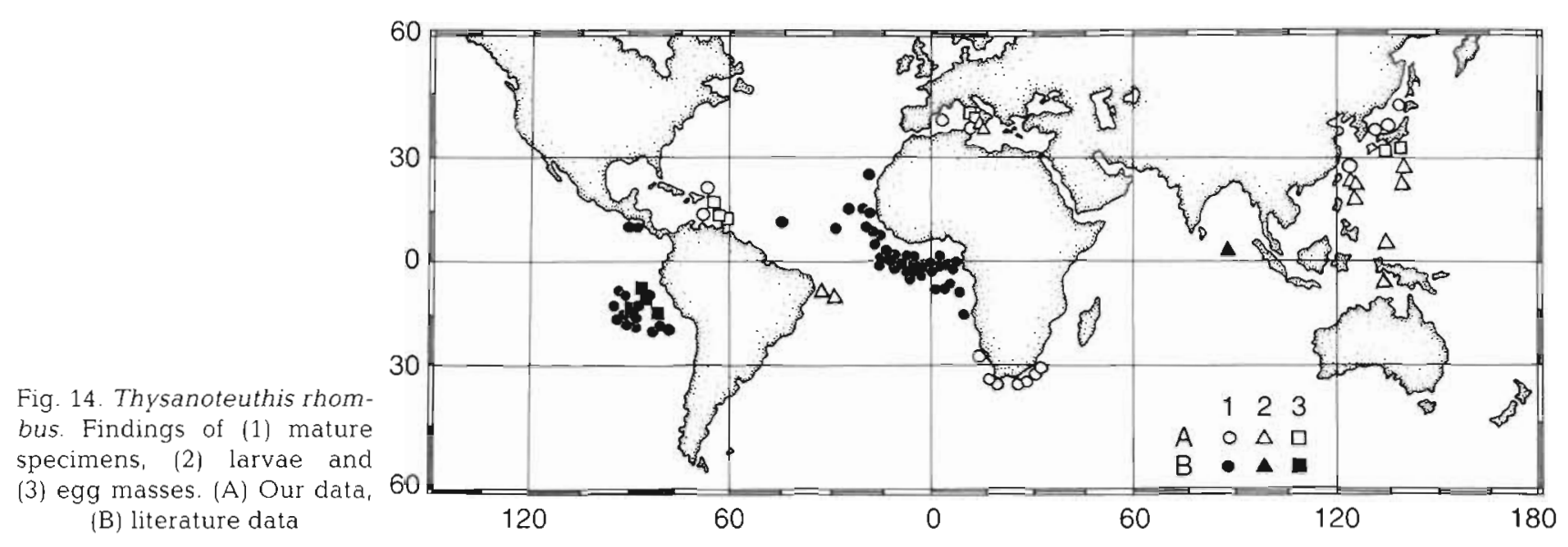

Spawning grounds

Spawning grounds of Thysanoteuthis rhombus were identified as those areas in which egg masses, larvae and completely mature squid were found (Fig. 14). These coincided almost completely with the species' geographic range (except for nearshore peripheral regions). All occurrences of $T$. rhombus egg masses, larvae and mature squid in peripheral regions corresponded with strong warm currents such as the Agulhas or Kuroshio (Nishimura 1966, Nazumi 1975. Roeleveld \& Pheiffer 1987).

Clearly, this squid does not reproduce in subtropical oligotrophic waters of the World Ocean, except in the Mediterranean Sea. Thysanoteuthis rhombus spawns throughout the year in tropical waters. In peripheral regions such as in the Mediterranean (Degner 1926. Sanzo 1929), near southern Japan (Yamamoto \& Okutani 1975, Misaki \& Okutani 1976) and in the southeast Pacific (Sabirov et al. 1987), spawning takes place during the warm seasons (summer and early autumn).

\section{DISCUSSION}

\section{Age and growth}

The statolith shape of Thysanoteuthis rhombus resembles that of shelf ommastrephids (i.e. Illex coindeti; Arkhipkin 1989) in its well-developed and smooth dorsal dome, relatively short rostrum and almost right rostral angle in adults. Statoliths of juveniles $(<100 \mathrm{~mm}$ $\mathrm{ML}$ ) are relatively large ( 2 to $2.68 \% \mathrm{ML}$ ), but owing to the strong negative allometry of statolith length versus mantle length, their relative sizes were very small in adults (up to $0.19 \% \mathrm{ML}$ ), whereas in oceanic ommastrephids statoliths of large adults were 1.7 to 2.3 times larger [i.e. in a mature Dosidicus gigas male of $724 \mathrm{~mm}$ $\mathrm{ML}, \mathrm{STL}=2.75 \mathrm{~mm}(0.38 \% \mathrm{ML})$, and in a mature
Sthenoteuthis pteropus female of $540 \mathrm{~mm} \mathrm{ML}, \mathrm{STL}=$ $1.75 \mathrm{~mm}(0.32 \% \mathrm{ML})$; our data]. Thus, in shape and possibly size, statoliths of T. rhombus resemble those of moderately active nektonic squids ( $I$. coindeti), but not those of highly active oceanic nektonic squids such as $D$. gigas and S. pteropus.

Statocysts of Thysanoteuthis thombus resembled those of non-buoyant oegopsids, but possessed unique characters. The statocyst volume of a $T$. rhombus adult of $800 \mathrm{~mm} \mathrm{ML}\left(11.61 \mathrm{~mm}^{3}\right)$ was one-seventh that in an omastrephid (Ommastrephes bartrami) of approximately the same size, $850 \mathrm{~mm} \mathrm{ML}\left(73.22 \mathrm{~mm}^{3}\right)$. The main differences in statocyst shape between $T$. rhombus and ommastrephids were the small knob-like anticrista 1 in $T$. rhombus, unlike the large rod of ommastrephids; and the presence of a large hamulus at the first turn of the crista, which is characteristic of Sepia but not of ommastrephids, and is possibly connected with the presence of long fins along the mantle of $T$. rhombus. It has been suggested that the statocyst of $T$. rhombus is less suited for rapid movement than in adult ommastrephids (Young 1989).

The shape of both the statocyst and statolith of Thysanoteuthis rhombus corresponds with its behavior and activity patterns. In contrast to other nektonic ommastrephid squids which are nictoepipelagic (Zuev et al. 1985), T. rhombus is a holopelagic species that makes diel migrations within the upper 100 to $200 \mathrm{~m}$ water layer (Roper et al. 1984, our data). The holopelagic lifestyle of $T$. rhombus is corroborated by its high oxygen requirements: the critical and threshold oxygen concentrations for T. rhombus juveniles were 2 and 3 times as high, respectively, as those for $S$. pteropus juveniles (Stolbov 1986). Despite its nektonic shape, $T$. rhombus is a low-activity migrant that undertakes long seasonal migrations in waters of warm peripheral currents. Therefore, $T$. rhombus may be characterized paradoxically as a planktonic nekteur. Underwater observations of $T$. rhombus behavior sup- 
port this assumption (Nigmatullin 1987). During a major part of its life, $T$. rhombus does not actively move, but rather is propelled slowly by the undulation of its long triangular fins. However, when it encounters a sudden danger $T$. rhombus is capable of making one or several powerful contractions of its muscular mantle and thus escaping the dangerous situation. Earlier, O'Dor et al. (1991) found in squid that the costs of movement by means of fin undulation were much lower than those due to mantle contractions. Thus, the behavior of $T$. rhombus leads to a decrease in the costs of active metabolism, enabling the squid to maintain very high growth rates (Figs. $8 \& 9$ ).

Growth rates of Thysanoteuthis rhombus juveniles of 25 to $300 \mathrm{~mm} \mathrm{ML}$ are strikingly high and close to the maximum known for other immature squid in this size range (Arkhipkin 1989, Jackson \& Choat 1992). As a result, $T$. rhombus juveniles quickly pass through the size range (ML 50 to $150 \mathrm{~mm}$ ) that is most vulnerable to active oceanic predators such as tunas, swordfish and squids, and thus reduce predation loss. There is no sexual dimorphism in the growth rates of $T$. rhombus. Males and females mature at age 6 to $8 \mathrm{mo}$ and live for around $12 \mathrm{mo}$. Therefore, the longevity of $T$. rhombus is about 1 yr similar to the majority of large neritic and oceanic ommastrephids and loliginids (Arkhipkin 1989, Jackson \& Choat 1992).

\section{Reproductive biology}

The sexual system of Thysanoteuthis rhombus may be characterized by a set of specific features such as structure and size of the oviducts and oviductal glands in females; size of the Needham sac, penis and spermatophores in males; and, in both sexes, the pattern of gonad attachment (Nigmatullin et al. 1991).

\section{Copulation}

Before spawning, the female and male mate in 'head to head' position. This is confirmed by the presence of spermatangues (mating traces) on the buccal membrane of females. During copulation, the male transfers the spermatophores to the female by the hectocotylus. In Thysanoteuthis rhombus, the fourth left arm is hectocotylized; 7 to 8 rows of suckers in the median of the arm shrink or even disappear. Several glands appear on the transformed region of the hectocotylus, which together with the dorsal protective membrane help in effective transportation and retention of the spermatophores (Nigmatullin et al. 1991). After ejaculation, spermatophores are attached to the surface of the female's buccal membrane. Nigmatullin et al. (1991) found from 3 to 6 sper- matangues in females. Spermatozoa from the spermatangues are transported via an unknown pathway into the seminal receptacles located on the ventral part of the buccal membrane. It is noteworthy that $T$. rhombus accumulates approximately the same volume of seminal fluid in several large spermatophores as the most fecund ommastrephid, Ommastrephes bartrami, which produces up to 1700-1800 small spermatophores containing a total of 5 to $9 \mathrm{~cm}^{3}$ of seminal fluid (Zalygalin et al. 1983).

\section{Functioning of the female sexual system}

Based on the structure of the sexual system and the number and types of oocytes within the ovary and oviducts of mature females, it is possible to propose a hypothesis describing the functioning of the sexual system of a Thysanoteuthis rhombus female. The total number of oocytes has formed in immature individuals by the end of maturity stage II. In the subsequent stages, the total amount of oocytes remains constant, but they start to develop asynchronously. As soon as the oocytes become ripe, they are released from the follicles into the sexual coelom and transferred to the oviducts, where they accumulate. Simultaneously with the accumulation of oocytes in the oviducts, the nidamental and oviductal glands are developing. When the oviducts have become completely filled with ripe eggs, a spawning takes place.

\section{Egg mass structure}

Until recently, a total of 21 egg masses of Thysanoteuthis rhombus had been found. All were found drifting in the surface water layer of the tropical Atlantic, northwest and southeast Pacific and the Mediterranean (review in Sabirov et al. 1987). The egg mass of $T$. rhombus is a dense, resilient, oblong cylinder with rounded tips (Fig. 15C). Their lengths varied from $600-800$ to $1500-1800 \mathrm{~mm}$ and their diameters from $110-150$ to $200-300 \mathrm{~mm}$. These variable lengths may correspond with the dimensions of the female. In the outer layer of the mucous cylinder there are 2 rows of crimson-purple eggs, spirally arranged around the cylinder. The total number of eggs in each egg mass varies from 32000 to 76000 (Sabirov et al. 1987).

\section{Egg mass formation}

In accordance with the specific characters in the structure of the accessory glands and egg masses of Thysanoteuthis rhombus, we propose 2 hypotheses regarding egg mass formation (Fig. 15). 


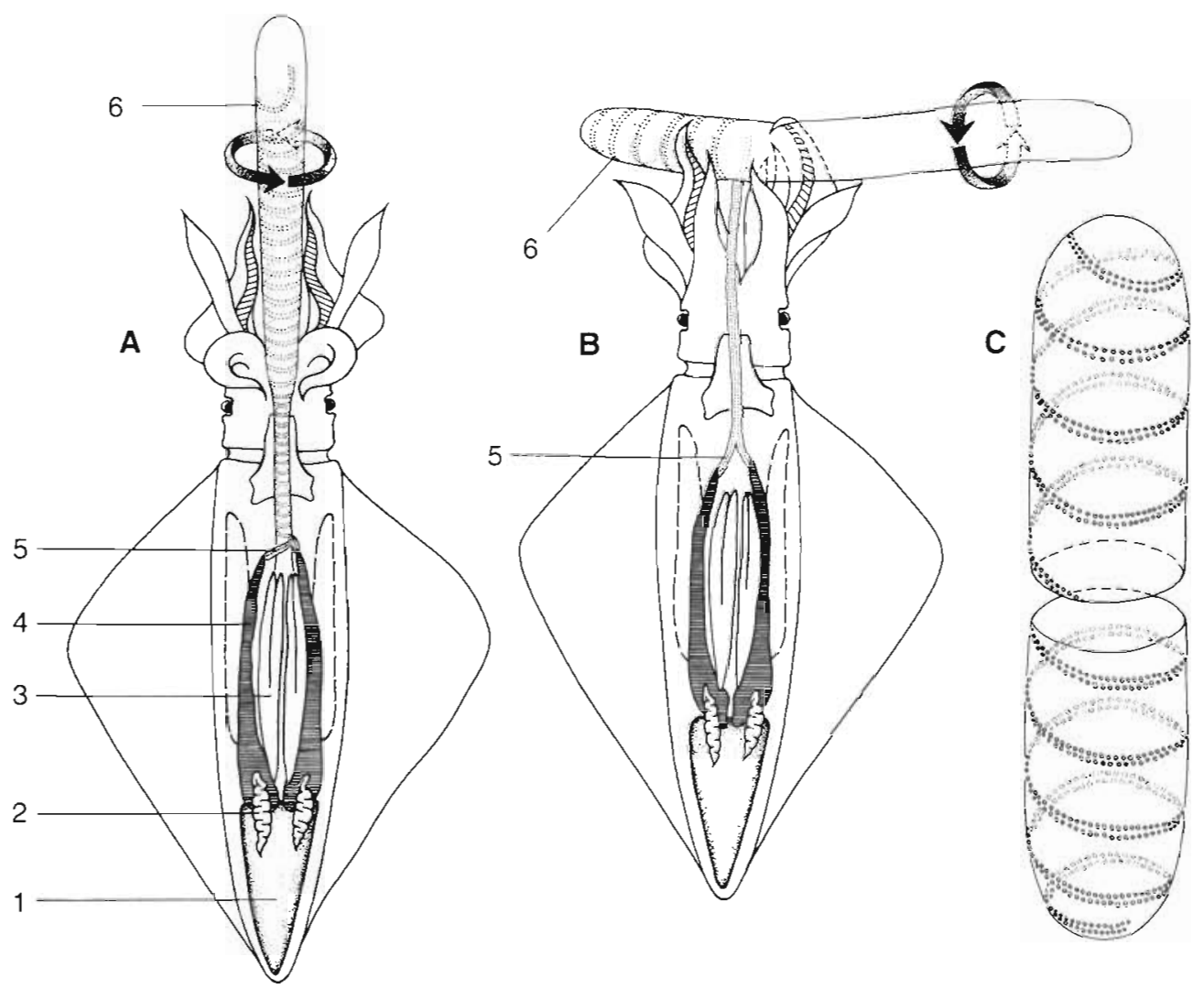

Fig. 15. Thysanoteuthis rhombus. Possible methods of egg mass construction by females. (A) Hypothesis 1, (B) hypothesis 2 , (C) schematic diagram of egg mass. 1: Ovary; 2: oviduct; 3: nidamental glands; 4: oviductal glands; 5 : secretion of oviductal glands with ripe eggs; 6 : egg mass

The first hypothesis. At spawning, both oviductal and nidamental glands secrete simultaneously. Secretions of the nidamental glands appear in the mantle cavity and form a mucous, cylindrical egg mass which exits through the funnel (Fig. 15A). After extrusion into the water, the mucous cylinder quickly swells and becomes neutrally buoyant. The female seizes the cylinder with her arms and starts to rotate it around the longitudinal axis. This time each oviductal gland forms a thin mucous thread with 1 row of ripe eggs in it. Threads from both oviductal glands fuse together and attach to the surface of the cylinder within the mantle cavity. As a result of the cylinder rotation, the 2 threads of eggs are wound onto the cylinder in a double spiral. After the cylinder swells in the water, the distance between the eggs in the spiral and between the loops of the spiral increases. The consistency of the mucous cylinder and threads is approximately the same, so the boundaries between them are poorly visible. In our opinion, this hypothesis has one weak point: one tip of the egg mass must be without eggs or bear a straight line of them (instead of spiral), because the first part of the cylinder remains unrevolved. But this has not been observed in actual egg masses.
The second hypothesis. Females of Thysanoteuthis rhombus first produce a secretion of the nidamental glands like that of the ommastrephid Todarodes pacificus (Hamabe 1962). The secretion enters the water, and swells, and the female molds it into a cylinder (Fig. 15B). After that, the oviductal glands start to work, forming 2 mucous threads, each with 1 row of eggs. In the mantle cavity both threads fuse and develop into a single cord containing a double row of eggs. This cord exits into the water through the funnel, and the eggs are fertilized with spermatozod from seminal receptacles located in the female's buccal membrane. The female then winds the cord of eggs onto the cylinder. As a result, the structure of the egg mass is uniform, as observed in natural egg masses of $T$. rhombus.

\section{Reproductive strategy}

Because of the large values of potential and realized fecundity, the rather small maximum volume of both oviducts in mature females (up to 140000 eggs) and the small volume of individual egg masses (35000 to 
76000 eggs), it is possible that Thysanoteuthis rhombus has multiple spawnings of the 'pulsate' type, i.e. with successive fillings and evacuations of the oviducts. During the spawning period, which lasts 2 to 3 mo, a female $T$. rhombus may produce about 8 to 12 egg masses if it utilizes all of its vitelline oocytes (average 600 000).

Thysanoteuthis rhombus appears to be characterized by a relatively low abundance and population density -5 to $20 \mathrm{~kg} \mathrm{~km}$-2 (Nigmatullin 1987). This seems to have led to a situation unique among squids, namely monogamy, where pairs consisting of a male and female of the same size remain together from their juvenile stage until death. We assume that the main function of this paired lifestyle is reproductive. Immature squids probably recognize the opposite sex by the sexual dimorphism in length of the third pair of arms: in males they are twice as long as in females (our data). This kind of behavioral strategy is optimal given the low density of $T$. rhombus populations and slow movement of squids (Nigmatullin 1987).

Thysanoteuthis rhombus displays a combination of characters of both $\mathrm{K}$ - and R-strategies. Among the features of the K-strategy are a relatively large size of eggs (1.8 mm in diameter; Sanzo 1929), embryogenesis in well-protected gelatinous egg mass, early escape from the pressure of oceanic predators, welldeveloped behavioral mechanisms and morphological adaptations for escaping predators, and large body dimensions. R-selection characters of $T$. rhombus include high fecundity, high growth rates, monocyclic reproduction and a short (1 yr) life span. Adaptations to peripheral, narrow ecological niches resulted in the specific lifestyle of $T$, rhombus and have enabled this species to survive despite the low density of its populations within the vast oceanic range.

Acknowledgements. We are particularly grateful to the staff of the Laboratory of Commercial Invertebrates of AtlantNIRO and to the Laboratory of Nekton of INBYUM (Sebastopol, Ukraine) for generous help in specimen collection. We thank K. N. Nesis for critical reading of the manuscript. Valuable comments of 3 anonymous referees greatly improved the manuscript. The research described in this publication was made possible in part by Grant No. NNF000 from the International Science Foundation

\section{LITERATURE CITED}

Arkhipkin AI (1989) Age and growth of the ommastrephid squid. PhD thesis, Institute of Oceanology, Moscow

Arkhipkin AI (1991) Methods for cephalopod age and growth studies with emphasis on statolith ageing techniques. In: Jereb P, Ragonese S, Boletzky S von (eds) Proceedings of an International Workshop, Mazara del Vallo, Italy, 9-14 October 1989. NTR-ITPP Spec Publ 1. Istituto di tecnologia della Pesca de del Pescato (ITPP-CNR). Mazara del Vallo. p $11-17$
Arkhipkin AI, Murzov SA (1986) Statolith morphology, growth and development in squids of the family Ommastrephidae from the south-eastern part of the Pacific Ocean. Zool Zh 64:499-505

Arkhipkin AI, Nigmatullin CM, Sabirov RM, Shilin KD (1983) Morphology and functional peculiarities of reproductive system of the squid, Thysanoteuthis rhombus. In Starobogatov YI, Nesis KN (eds) Taxonomy and ecology of cephalopods. Nauka Press, Leningrad, p 59-61

Barnard KH (1947) Rare squid at the Cape (Thysanoteuthis rhombus Trosch.). J Conchol 22:286

Bigelow KA (1992) Age and growth in paralarvae of the mesopelagic squid Abralia trigonura based on daily growth increments in statoliths. Mar Ecol Prog Ser 82 $31-40$

Blanquaert $T$ (1925) L'origine et la formation des spermatophores chez les cephalopodes decapodes. Cellule 36 : $315-356$

Brock J (1882) Zur Anatomie und Systematik der Cephalopoden. Z wiss Zool 36:543-610

Bruggen AC van (1962) Notes on South African Marine Mollusca. 6. Thysanoteuthis rhombus (Cephalopoda) in Algoa Bay. Annls Natal Mus 15:267-272

Burukovskii RN, Zuev GV, Nigmatullin CM. Tsymbal MA (1977) Methodical bases for working out the scales of reproductive system maturity in the squid females, Sthenoteuthis pteropus (Cephalopoda, Ommastrephidae) taken as an example. Zool Zh 56:1781-1791

Clarck FN (1934) Maturity of the California sardine (Sardina caerulea), determined by ova diameter measurements. Fish Bull US 42:1-49

Clarke MR (1978) The cephalopod statolith - an introduction to its form. J mar biol Ass UK 58:701-712

Dawe EG, Natsukari Y (1991) Light microscopy. In: Jereb P, Ragonese $S$, Boletzky $S$ von (eds) Proceedings of an International Workshop, Mazara del Vallo, Italy, 9-14 October 1989. NTR-ITPP Spec Publ 1. Istituto di tecnologia della Pesca de del Pescato (ITPP-CNR). Mazara del Vallo, p $83-96$

Dawe EG, O'Dor RK, Odense PH, Hurley GV (1985) Validation and application of an ageing technique for shortfinned squid (Illex illecebrosus). J Northw Atl Fish Sci 6: $107-116$

Degner E (1926) Cephalopoda. Rep Dan oceanogr Exped Mediterr 2:1-94

Hamabe M (1962) Embryological studies on the common squid, Ommastrephes sloani pacificus Steenstrup, in the southeastern waters of the sea of Japan. Bull Jap Sea reg Fish Res Lab 10:1-45

Hixon RE, Villoch MR (1984) Growth rings in the statoliths of young laboratory cultured squids (Loligo opalescens). Am malacol Bull 2:93

Jackson GD (1990) Age and growth of the tropical nearshore loliginid squid Sepioteuthis lessoniana determined from statolith growth-ring analysis. Fish Bull US 88:113-118

Jackson GD. Choat JH (1992) Growth in tropical cephalopods: an analysis based on statolith microstructure. Can J Fish Aquat Sci, 49:218-228

Lipinski MR (1986) Methods for the validation of squid age from statoliths. J mar biol Ass UK 66:505-526

Misaki H, Okutani T (1976) Studies on early life history of decapodan Mollusca - VI. An evidence of spawning of an oceanic squid, Thysanoteuthis rhombus Troschel, in the Japanese waters. Jap J Malac (VENUS) 35:211-213

Morales E (1981) Presencia de Thysanoteuthis rhombus Troschel, en el puerto de Mahan (Menorca). Invest Pesq $45: 17-20$ 
Nakamura Y, Sakurai Y (1991) Validation of daily growth increments in statoliths of Japanese common squid, Todarodes pacificus. Nippon Suisan Gakk 57:2007-2011

Nazumi T (1975) Notes on the fishery and the ecology of the squid, Thysanoteuthis rhombus Troschel, in the east San'in waters. Bull Hyogo Pref Fish exp Stn 15:15-34

Nesis KN (1985) Oceanic cephalopods: distribution, living forms, evolution. Nauka Press, Moscow

Nigmatullin CM (1987) Behavior of the epipelagic nektonic squids of Ommastrephidae and Thysanoteuthidae families. Infor Bull Freshwat Biol 73:51-54

Nigmatullin CM, Arkhipkin AI, Sabirov RM (1991) Structure of the reproductive system of the squid. Thysanoteuthis rhombus (Cephalopoda: Oegopsida). J Zool 224: 271-283

Nishimura S (1966) Notes on the occurrence and biology of the oceanic squid, Thysanoteuthis rhombus Troschel, in Japan. Publ Seto mar Biol Lab 14:327-349

O'Dor RK, Hoar JA Webber DM (1991) The role of fins in the competition between squid and fish. J mar biol Ass UK $71(3): 718$

Osako M, Murata M (1983) Stock assessment of cephalopod resources in the Northwestern Pacific. FAO Fish tech Pap 231:55-144

Pfeffer G (1912) Die Cephalopoden der Plankton-Expedition. Ergebn Plankton-Exped 2:1-815

Ricker WE (1958) Handbook of computation for biological statistics of fish populations. J Fish Res Bd Can 119:1-300

Roeleveld M, Pheiffer F (1987) The diamond squid. Sagittarius 2:20-22

Roper CFE, Sweeney MJ, Nauen CE (1984) FAO species catalogue, Vol 3, Cephalopods of the world. An annotated and illustrated catalogue of species of interest to fisheries.

This article was submitted to the editor
FAO Fish Synop 125

Roper CFE, Voss GL (1983) Guidelines for taxonomic descriptions of cephalopod species. Mem natn Mus Victoria 44: $48-64$

Sabirov RM, Arkhipkin AI, Tsygankov VY, Schetinnikov AS (1987) Egg laying and embryonal development of diamond-shaped squid, Thysanoteuthis rhombus (Oegopsida, Thysanoteuthidae). Zool Zh 66:1155-1163

Sanzo L (1929) Nidamento pelagico, uova e larve di Thysanoteuthis rhombus Troschel. Mem R Com talassogr ital 161. 3-9

Stolbov AY (1986) Respiration of juvenile oceanic squids in the tropical Atlantic. In: IVth All-Union conference on the commercial invertebrates, Sebastopol, April 1986. VNIRO Press, Moscow, p 157-158

Vigelius WJ (1881) Untersuchungen an Thysanoteuthis rhombus Trosch. Ein Beitrag zur Anatomie der Cephalopoden. Mitt zool Stn Neapel 2:150-161

Yamamoto K, Okutani T (1975) Studies on early life history of decapodan Mollusca. V. Systematics and distribution of epipelagic larvae of decapod cephalopods in the southwestern waters of Japan during the summer 1970. Bull Tokai reg Fish Res Lab 83:45-96

Young JZ (1989) The angular acceleration receptor system of diverse cephalopods. Phil Trans $R$ Soc Lond $B$ 325: $189-237$

Zalygalin VP, Nigmatullin CM, Sabirov RM (1983) Morphology and function of the male reproductive system in the squid Ommastrephes bartrami Lesueur. In: Starobogatov YI, Nesis KN (eds) Taxonomy and ecology of cephalopods. Nauka Press, Leningrad, p 62-64

Zuev GV, Nigmatullin CM, Nikolski VN (1985) Oceanic nektonic squid. Agropromizdat Press, Moscow

Manuscript first received: April 5, 1994

Revised version accepted: February 16, 1995 